\title{
Zebrafish fin immune responses during high mortality infections with viral haemorrhagic septicemia rhabdovirus. A proteomic and transcriptomic approach
}

\author{
Paloma Encinas', Miguel A Rodriguez-Milla ${ }^{1}$, Beatriz Novoa², Amparo Estepa ${ }^{3}$, Antonio Figueras², Julio Coll ${ }^{1 *}$
}

\begin{abstract}
Background: Despite rhabdoviral infections being one of the best known fish diseases, the gene expression changes induced at the surface tissues after the natural route of infection (infection-by-immersion) have not been described yet. This work describes the differential infected versus non-infected expression of proteins and immunerelated transcripts in fins and organs of zebrafish Danio rerio shortly after infection-by-immersion with viral haemorrhagic septicemia virus (VHSV).

Results: Two-dimensional differential gel electrophoresis detected variations on the protein levels of the enzymes of the glycolytic pathway and cytoskeleton components but it detected very few immune-related proteins. Differential expression of immune-related gene transcripts estimated by quantitative polymerase chain reaction arrays and hybridization to oligo microarrays showed that while more transcripts increased in fins than in organs (spleen, head kidney and liver), more transcripts decreased in organs than in fins. Increased differential transcript levels in fins detected by both arrays corresponded to previously described infection-related genes such as complement components (c3b, c8 and c9) or class I histocompatibility antigens ( $m h c 1)$ and to newly described genes such as secreted immunoglobulin domain (sid4), macrophage stimulating factor (mst1) and a cluster differentiation antigen (cd36).

Conclusions: The genes described would contribute to the knowledge of the earliest molecular events occurring in the fish surfaces at the beginning of natural rhabdoviral infections and/or might be new candidates to be tested as adjuvants for fish vaccines.
\end{abstract}

\section{Background}

The gene expression changes occurring in the surface tissues of fish after rhabdoviral natural infections have not been described yet. In the most studied infectionby-injection models, internal organs are affected by the infection before surface tissues, while the contrary is expected to occur in the infection-by-immersion models which mimick the natural route of infection.

Under laboratory controlled conditions, trout rhabdoviral infections produce $100 \%$ mortalities after infectionby-injection, while only $60-80 \%$ wild type $[1,2]$ or $5 \%$

\footnotetext{
* Correspondence: juliocoll@inia.es

'Instituto Nacional Investigaciones Agrarias, Dpto. Biotecnología. INIA. Crt. La Coruña, Km. 7, 28040 - Madrid, Spain

Full list of author information is available at the end of the article
}

rhabdoviral-resistant [3-5] mortalities could be obtained after infection-by-immersion. These results suggested that the natural route of infection is an important determinant for the final outcome of fish rhabdoviral diseases.

Some infection-by-immersion studies using recombinant viruses showed that the fin bases, skin and other fish epithelial surfaces were the earliest sites of replication for rhabdoviral [6] and other viral [7] infections. Furthermore, after viral haemorrhagic septicemia (VHSV) infection, zebrafish showed early hemorrhages in the skin, fin bases, mouth and gills long before dying [8]. The fin bases therefore, were chosen for this study as a representative fish surface tissue and because they were easy and reproducibly harvested. From the fish 
surface tissues, rhabdoviruses spread to the fish internal organs [6,9]. Therefore, internal organs (spleen, head kidney and liver) were also chosen as potential tissue responders to delayed infection-by-immersion and to compare their responses with those obtained at the fin bases.

The zebrafish Danio rerio was chosen because the sequence of their genome is well advanced and $\sim 40 \mathrm{~K}$ annotated quantitative polymerase chain reaction (Q-PCR) arrays or partially annotated oligo microarrays are available. Furthermore, zebrafish are susceptible to several rhabdoviruses of fish farmed species [2,10-12], whose infection severity can be modulated by viral dosage and temperature. VHSV was selected among the other rhabdoviruses because of their importance in fish aquaculture and because protection and adaptative immune responses to VHSV-challenges after vaccination have been demonstrated in cold-acclimatized zebrafish [8]. Lower than physiological optimal temperatures induce a delay on fish adaptative immune responses while some of the innate immune responses (complement, phagocytosis, etc) are up regulated [13]. However, little is known about the detailed gene regulation implicated in innate responses in fish when temperature decreases and viral susceptibility becomes maximal, such as it occurs during most rhabdoviral natural outbreaks $[1,14]$.

Therefore, the differential (infected versus noninfected ) protein and immune-related transcript expression of zebrafish fin tissues after VHSV infection-byimmersion were the focus of this work. The results demonstrated the important variability associated with in vivo fish experiments. At the protein level and despite variability, VHSV-infection changed the differential expression levels of most fin enzymes of the glycolytic pathway and their cytoskeleton proteins. However, because most immune-related proteins remained undetectable by the proteomic approach, their RNA expression levels need to be also investigated. At the transcriptional level, VHSV-infection increased the differential expression of several fin immune-related genes while decreased those of the internal organs. While these findings shed some light upon the earliest effects of VHSV infection-by-immersion at the molecular level, some of the newly described genes might even be used for adjuvant testing purposes.

\section{Results}

\section{Infection-by-immersion of cold-acclimatized zebrafish} with VHSV

Cold acclimatized zebrafish infected-by-immersion in $2 \times$ $10^{6}$ focus forming units (ffu) of VHSV per $\mathrm{ml}$, at $14^{\circ} \mathrm{C}$ induced mortalities of $80-100 \%$. Under those conditions, most zebrafish showed the first external hemorrhages around the mouth and gills, in the lateral skin or in the fin bases, 5-7 days post infection (see one example of external hemorrhages at the fin bases on Figure 1A).

Although every individual zebrafish followed a different time course of VHSV spreading to its body until its death, 2-days after infection-by-immersion there were no mortalities in any of the different experiments performed ( $n=6$, each experiment consisting of 10 zebrafish). The time courses of subsequent mortalities (Figure 1B) were delayed a few days (50\% mortalities occurring 12-20 days after infection) compared to those previously reported in trout $(50 \%$ mortalities occurring

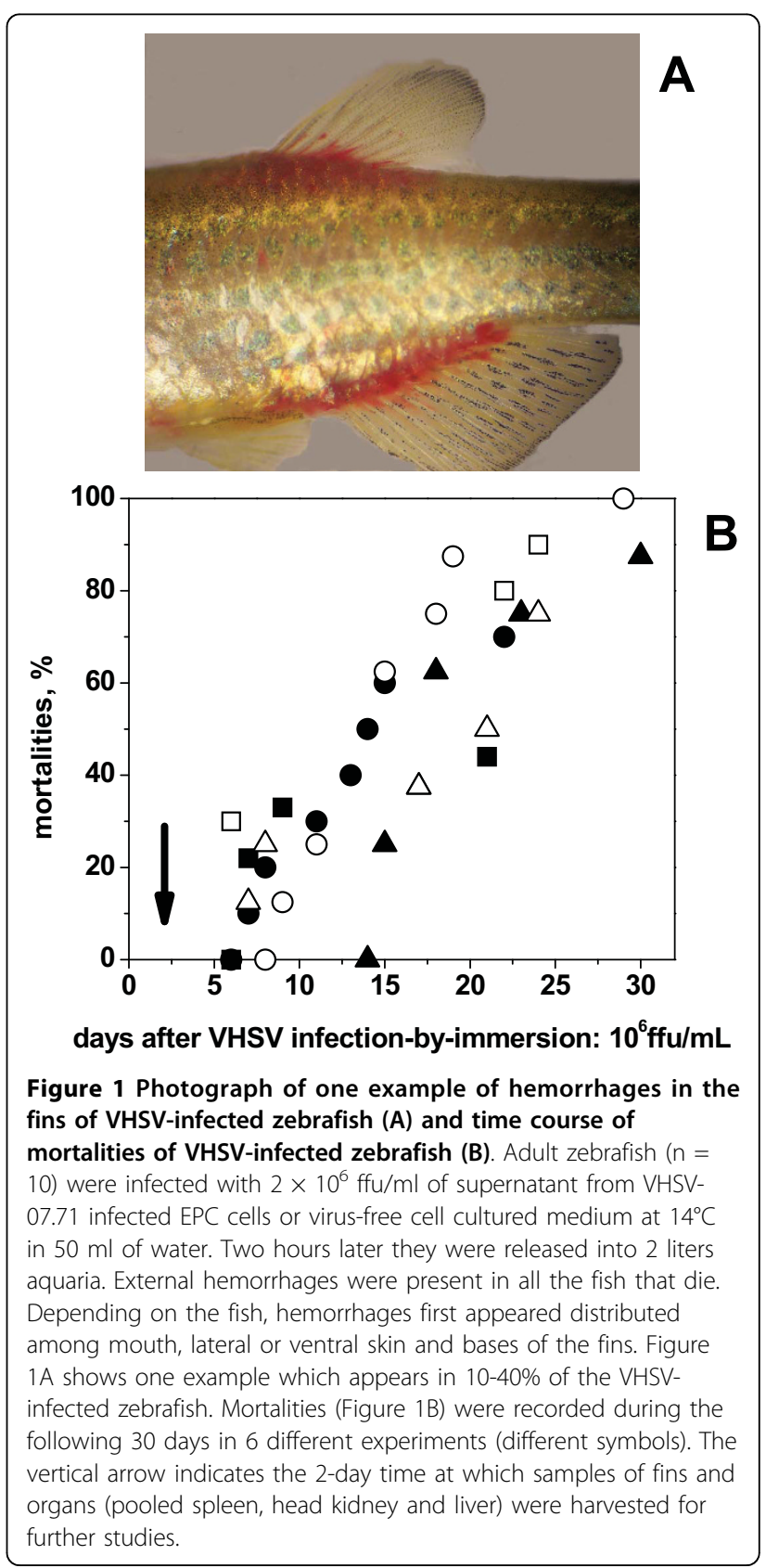


8-10 days after infection) [15]. Previous zebrafish acclimatation to $14^{\circ} \mathrm{C}$ during 7 days was required for the VHSV infection to cause high mortalities, confirming previous results [8]. Reduction of the acclimatation time from 7 to 1 days, reduced to $10-30 \%$ the mortalities (not shown).

Two days after infection-by-immersion, VHSV N mRNAs levels corresponded to $0.36 \times 10^{6} \mathrm{ffu}$ of VHSV in the fins and $0.007 \times 10^{6} \mathrm{ffu}(51.4$-fold less) in the organs (pooled spleen, head kidney and liver) per individual zebrafish (averages from 3 experiments, 10 zebrafish per experiment) (data not shown).

Studies on the protein and transcript differential changes occurring on zebrafish fins or organs, 2-days after infection-by-immersion at high mortality conditions were then undertaken.

\section{Protein changes in the zebrafish fins induced by VHSV infection by 2D-DIGE}

Figure 2 illustrates a representative two dimensional differential gel electrophoresis (2D-DIGE) image of

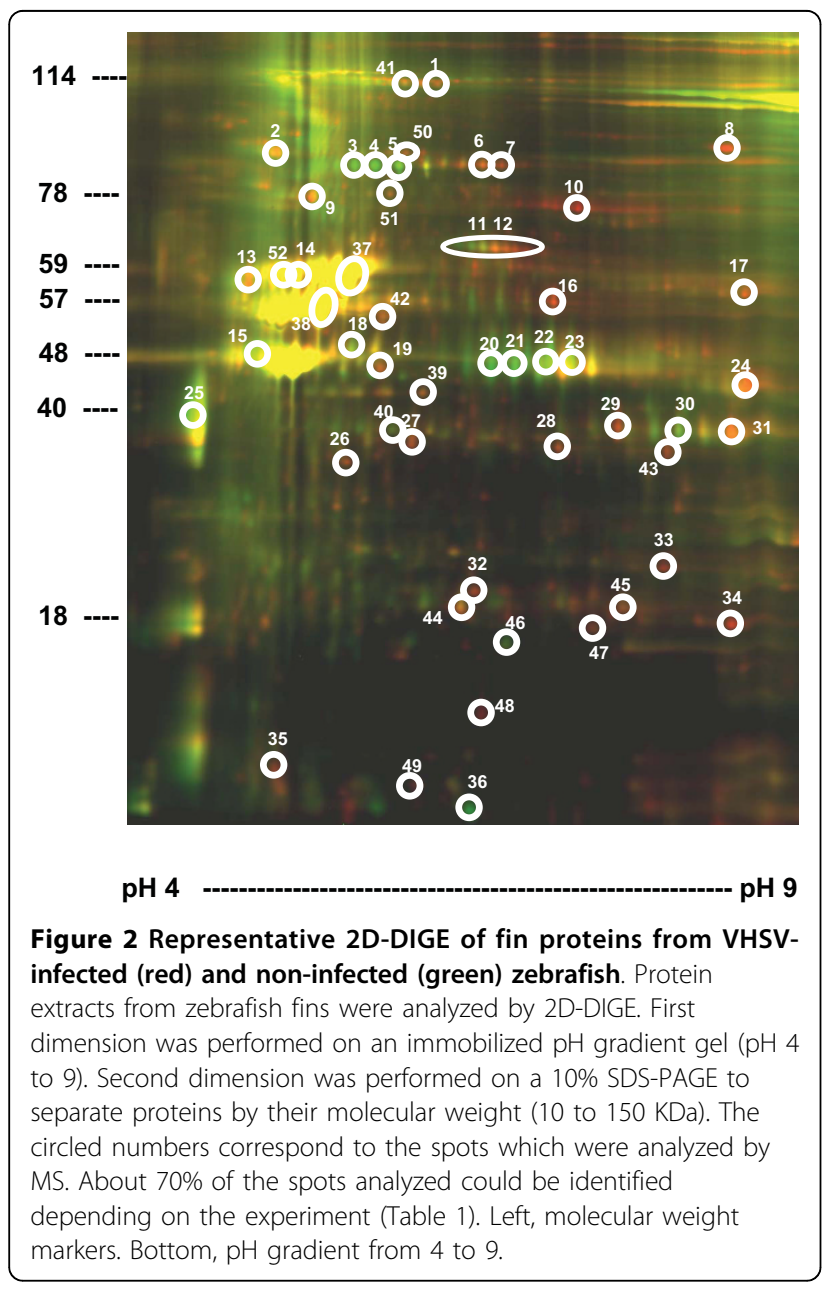

comparative protein profiles from VHSV-infected (red) and non-infected (green) fins. About 300 spots in each Sypro Ruby-stained gel were visualized (data not shown). Depending on the experiment, 50-100 spots, that may represent different proteins, degrees of protein modification and/or degradation products were differentially expressed.

The characteristic protein profile of zebrafish fins showed three major multiple spot regions between 48-57 KDa distributed around isoelectric points ( $\mathrm{pI}$ ) of $\sim 5$. Their yellow color confirmed that their levels remained unchanged after VHSV infection. Most of the differentially expressed protein spots (decreased in green or increased in red) were between 18 and 78 KDa. The most differentially expressed spots (circled spots on Figure 2) were excised, in-gel digested with trypsin, and analyzed by mass spectrometry (MS). Protein identifications summarized in Table 1 showed that the characteristic major yellow spots corresponded to keratins $(\sim 57 \mathrm{KDa})$, cytokeratins $(\sim 52 \mathrm{KDa})$ and actins ( 42 KDa) (Figure 2).

Most of the enzymes of the glycolytic pathway increased upon VHSV infection, such as fructose-bisphophate aldolase, triose phosphate isomerase, glyceraldehyde 3phosphate dehydrogenase ( $\mathrm{gadph}$ ), phosphopyruvate dehydratase (enolase) and lactate dehydrogenase. Also an ATP binding protein was decreased, while an ATP synthase was increased, most probably contributing with all the above enzymes to ATP accumulation in the VHSVinfected fins (Table 1).

The levels of different types of keratins specific for epithelial cells were maintained after VHSV infection (characteristic yellow spots mentioned above) while others such as keratin 18, type I and type II cytokeratins increased. Skeletal $\alpha$-actin, $\alpha$-tropomiosin, kinesin and filament-actin (F-actin) crosslinking transgellin decreased after VHSV infection suggesting the reduction of F-actin networks. Myosins, CapG, scinderin, cyclaseassociated protein-1, dynamin and semaphorin also changed after VHSV infection.

Annexins (proteins related to apoptosis) A1a and 1a increased while annexins A5b and 5b decreased with VHSV infection. Proteins implicated in haematopoiesis such as transferrins and hemopexins increased, as probably demanded by the hemorrhages caused by VHSV infection. Increase of 4 isoforms of $f g f 20$, a protein implicated in fin regeneration were also detected in one of the experiments (Table 1).

VHSV proteins were searched among those spots located in their expected molecular weight/pI regions on the $2 \mathrm{D}$ gels. However, none could be detected, most probably due to their relative low abundance among the fin proteins 2-days after infection. 
Among the few immune-related proteins which could be detected by this approach, only the high mobility group binding 1 ( $h m g b 1$, spot 47 ) protein and the guanine nucleotide binding protein $\beta$ polypeptide 1 ( $g n b 1$, spot 26) could be detected. Both increased after VHSV infection. Because of the scarce number of immunerelated proteins detected by the 2D-DIGE experiments, most probably due to their low concentrations in fins, studies on the VHSV-induced transcripts by using immune-related Q-PCR arrays and hybridization to oligo microarrays were then undertaken.

\section{Immune-related transcripts changing in fins and organs after VHSV infection analyzed by Q-PCR arrays}

Differential expression with $>2$-fold and $p<0.05$ estimated by Q-PCR arrays showed that while 17 immune-related transcripts increased in fins, only 2 (c9 and $s l a / l p l$ ) increased in organs (Table 2). Furthermore, maximal differential transcript levels of any $\mathrm{p}$ value were of $\sim 36$-fold in fins, while only of $\sim 10$ fold in organs (Figure 3 ).

Complement component fin transcripts corresponding to $c 3 b, c 8 g$ and $c 9$ increased after VHSV infection (Table 2), while the same transcripts did not increased in organs, except $c 9$ (Table 2).

Major histocompatibility complex class I (mhc1uba) transcripts, one of the induced host molecules identified in most infections-by-injection, increased more than 3 -fold in the fins, however, it was not increased in organs (Table 2). Other differentially increased transcripts in fins which were not increased in organs were those corresponding to the secreted immunoglobulin domain 4 (sid4) of the immunoglobulin superfamily, and macrophage stimulating factor (mst1). Among all the cluster differentiation $(c d)$ antigen transcripts present in the immune-related probes ( $c d 2, c d 247, c d 36, c d 63$, $c d 9)$, only $c d 36$ and $c d 9$ were differentially increased in fins but not in organs (Table 2).

Among the transcripts corresponding to the interleukin (IL) genes studied (il1b, il10, il12a, il15, il17a/f1. il17a/f2, il17a/f3, il17c, il17 $d$, il22 and il26), only il17 $d$ and its related $i l 22$ (both produced by T17 helper cells) were differentially increased in fins. Some of the other il17 family members such as ill7a/f1 and il17 $d$ were also increased in fins, however, with $\mathrm{p}>0.05$ (not shown). There were not similar increases in organs for any of the studied IL transcripts (Table 2 and Figure 3).

Interferon (ifn1) transcripts, which increased > 2-fold in zebrafish organs after VHSV infection-by-injection in a previous report [8], did not changed at the fins/organs after infection-by-immersion (1.11/-1.44-fold, respectively). However, the primers designed to estimate ifn1 by the Q-PCR gene expression assay (Dr03100938_m1), only amplified the virus-independent if 1 isoform which remains unaltered upon viral infection [16].
Defensin $\beta$ (defbl2) increased in organs and fins (Figure 3) but it was eliminated from Table 2, because both of their transcript levels showed p $>0.05$.

No immune-related gene transcripts decreased $>2$ fold in fins (Table 2), while of the 7 transcripts that decreased $>2$-fold in organs, only $c r f b 12$ have $\mathrm{p}<0.05$ (Table 2).

\section{Immune-related transcript changes in fins/organs after VHSV infection by hybridization to oligo microarrays}

The signal intensities obtained after hybridization of samples from zebrafish fins and organs to microarrays, ranged from 0 to $\sim 550.000$ fluorescence units. Differential expression changes were then calculated by comparing VHSV-infected versus non-infected samples. Of the 43803 oligo sequences present in the zebrafish microarray latest version, $1175(2.68 \%)$ or $730(1.66 \%)$ in fins or organs, respectively, showed $>3$-fold increases (original data deposited in GSE19049). On the other hand, $14.78 \%$ or $11.70 \%$ in fins or organs, respectively showed a significant departure from the null hypothesis when $t$ tests were performed at the $\mathrm{p}<0.05$ significance level. Of the 636 immune-related sequences annotated in the zebrafish microarray, $35(5.5 \%)$ in fins and $7(1.1 \%)$ in organs increased $>2$-fold with $\mathrm{p}<0.05$ after VHSV infection. In contrast, $2(0.3 \%)$ sequences in fins and 23 $(3.6 \%)$ in organs decreased $>2$-fold after VHSV infection (Table 3).

The genes corresponding to the proteins identified in the proteomic analysis were searched in the microarray data and a column with that data added to Table 1. Because they were present in several copies per microarray, the averages of their differential transcriptional levels were calculated and represented. Although some of the increased (transferrin and hemopexin) and decreased (annexin A5b, ATP binding, alpha actin, and kinesin) proteins showed a similar change in their differential transcript levels, the rest of protein changes did not correlate with those of their corresponding transcripts.

Many complement transcripts ( $c 3$ precursor, $c 9, c f b$, $c f b / c 2 b, c 8 a, c r p p, c f h p$, and $c 6)$ including those increased in the Q-PCR arrays $(c 9, c 3 b$ and $c 8 g)$, increased in fins (Table 3). Only the $c 9$ transcripts increased in both fins and organs (Table 3 and Figure 4), as confirmed by 3 different oligo sequences of the same gene present in the microarray. Sequences for the rest of complement related genes $(c 2, c 4, c 5$ or $c 7$ genes) were neither present in the microarray (GSE19049) nor in the Q-PCR array (GSE19503). Increased $c 1 q$ transcripts (antibody-dependent complement pathway) were only found increased in organs but with $\mathrm{p}>0.05$ (Figure 4).

Of the 29 major histocompatibility complex $(m h c)$ sequences present in the annotated immune-related 
Table 1 Differential expression of proteins from fins by 2D-DIGE (Exp1, Exp2 and Exp3) and of their corresponding transcripts by hybridization to oligo microarrays

\begin{tabular}{|c|c|c|c|c|c|c|c|c|}
\hline Spot $n^{\circ}$ & Protein Name & Accession Number & $\sim \mathrm{MW} \times 10^{-3}$ & $\sim \mathrm{pl}$ & fold & fold & fold & microarray \\
\hline \multicolumn{9}{|c|}{ SIGNALING } \\
\hline 47 & hmgb1 & 42476233 & 16 & 7.0 & 2.4 & *3.7 & - & 1.01 \\
\hline 26 & gnb1 (G prot), $\beta$ polypep1 & 47087315 & 35 & 5.6 & 2.6 & 3.0 & - & 1.03 \\
\hline \multicolumn{9}{|c|}{ APOPTOSIS } \\
\hline 27 & Annexin A1a & 31419751 & 40 & 6.0 & 2.3 & 9.1 & - & 1.01 \\
\hline 39 & Annexin 1a & 27762256 & 44 & 6.2 & 2.5 & - & - & N.F. \\
\hline 0 & Annexin A5b & 41107552 & 36 & 5.2 & - & - & -2.0 & -1.08 \\
\hline 0 & Annexin 5b & 160773369 & 36 & 5.3 & - & - & -1.9 & N.F. \\
\hline \multicolumn{9}{|c|}{ DETOXIFICATION } \\
\hline 34 & Glutathion S-Transferase & 18858197 & 16 & 8.2 & 11.0 & $* 2.7$ & - & 1.30 \\
\hline 32 & Glutathion S-Transferase & 47086689 & 20 & 6.4 & 4.0 & $* 2.1$ & - & 1.30 \\
\hline \multicolumn{9}{|c|}{ HAEMATOPOIESIS } \\
\hline 10 & Transferrin & 51859259 & 70 & 6.9 & 16.1 & $* 4.6$ & - & 2.40 \\
\hline 11 & Hemopexin & 33991748 & 65 & 6.3 & 2.5 & *3.2 & - & 5.42 \\
\hline 12 & Hemopexin & 33991748 & 65 & 6.5 & 3.5 & - & - & 5.42 \\
\hline \multicolumn{9}{|c|}{ GLYCOLYSIS \& ATP } \\
\hline 24 & Aldolase fructose-bisphosphate & 37595414 & 44 & 8.3 & 5.7 & 8.2 & ${ }^{*} 1.4$ & 1.15 \\
\hline 45 & Triosephosphate isomerase $1 \mathrm{~b}$ & 47271422 & 18 & 7.1 & 2.1 & ${ }^{*} 1.5$ & 1.5 & 1.00 \\
\hline 29 & GAPDH & 56718619 & 42 & 7.2 & 5.3 & 10.2 & ${ }^{*} 1.8$ & 1.12 \\
\hline 31 & GADPH & 53733367 & 40 & 8.2 & 4.2 & 8.7 & - & 1.12 \\
\hline 4 & GAPDH & 53733367 & 85 & 5.6 & -7.4 & - & $-* 1.7$ & 1.12 \\
\hline 16 & Alpha enolase 1 & 37681795 & 57 & 6.7 & 6.0 & 17.6 & 1.8 & 1.18 \\
\hline 28 & Ldhb Lactate dehydrogenase & 28277619 & 35 & 6.8 & 3.3 & - & $* 2.2$ & 1.04 \\
\hline 33 & Carbonic anhydrase & 18858379 & 22 & 7.8 & 10.4 & - & - & -1.04 \\
\hline 43 & Malate dehydrogenase & 47085883 & 40 & 7.8 & 2.1 & $* 1.7$ & - & 1.05 \\
\hline 3 & ATP binding & 51571925 & 85 & 5.5 & -19.1 & - & - & -2.22 \\
\hline 0 & ATP synthase & 41152334 & 24 & 7.0 & - & - & 1.5 & 1.05 \\
\hline 46 & Creatine kinase & 55716037 & 15 & 6.5 & -3.4 & - & $-* 1.7$ & 3.16 \\
\hline 20 & Creatine kinase & 55716037 & 48 & 6.4 & -3.9 & - & $-* 2.0$ & 3.16 \\
\hline 5 & Creatine kinase & 55716037 & 90 & 5.9 & -4.0 & - & $-* 2.0$ & 3.16 \\
\hline \multicolumn{9}{|c|}{ CYTOSKELETON \& RELATED PROTEINS } \\
\hline 42 & Keratin 18 & 41351240 & 57 & 5.3 & 3.2 & 11.2 & - & 1.08 \\
\hline 38 & Keratin type I & 50370316 & 57 & 5.6 & 2.4 & - & - & 1.09 \\
\hline 13 & Type II cytokeratin & 18858425 & 59 & 5.1 & 3.2 & 1.0 & - & 1.23 \\
\hline 50 & Tubulin, gamma assoc protein 2 & 41056243 & 85 & 6.0 & 2.4 & - & - & -1.01 \\
\hline 30 & Skeletal alpha-actin (S. aurata) & 6653228 & 38 & 7.9 & -2.7 & -2.8 & - & -1.53 \\
\hline 21 & Alpha-tropomyosin & 18859505 & 44 & 6.6 & - & 3.4 & 7.2 & 1.56 \\
\hline 0 & Alpha-tropomyosin & 55962544 & 36 & 5.0 & - & - & 11.7 & 1.56 \\
\hline 15 & Transgelin & 37681953 & 49 & 5.2 & -7.4 & - & - & 1.49 \\
\hline 22 & Kinesin-like protein & 50055013 & 50 & 6.7 & -2.7 & - & - & -2.5 \\
\hline 41 & Myosin Vla & 10116291 & 114 & 5.9 & 2.0 & $* 5.1$ & 7.7 & 1.05 \\
\hline 0 & Myosin, light chain 2 & 18859049 & 22 & 5.0 & - & - & 7.3 & 1.30 \\
\hline 19 & CapG & 29612467 & 48 & 5.3 & 2.8 & $* 7.6$ & - & -1.08 \\
\hline 0 & Actin capping protein & 41053959 & 34 & 5.7 & - & - & -1.6 & 1.09 \\
\hline 6 & Scinderin & 42542770 & 80 & 6.4 & 4.1 & - & - & -1.14 \\
\hline 7 & Scinderin & 42542770 & 80 & 6.5 & 3.8 & - & - & -1.14 \\
\hline 17 & Cyclase-associated protein-1 & 37725381 & 58 & 8.3 & 5.0 & - & - & 1.66 \\
\hline 35 & Dynamin 1-like & 41055508 & 5 & 5.3 & 3.0 & - & - & 1.01 \\
\hline 48 & Semaphorin 3Gb & 57790316 & 7 & 6.4 & 3.0 & - & - & 1.09 \\
\hline 14 & Ckll protein & 39645432 & 65 & 5.3 & 2.9 & - & - & 1.13 \\
\hline
\end{tabular}


Table 1 Differential expression of proteins from fins by 2D-DIGE (Exp1, Exp2 and Exp3) and of their corresponding transcripts by hybridization to oligo microarrays (Continued)

\begin{tabular}{|c|c|c|c|c|c|c|c|c|}
\hline 0 & fgf20 fin regeneration & 51571925 & 26 & 6.2 & - & - & 1.8 & 1.26 \\
\hline 0 & fgf20 fin regeneration & 51571925 & 26 & 6.9 & - & - & 2.2 & 1.26 \\
\hline 0 & fgf20 fin regeneration & 51571925 & 26 & 7.0 & - & - & 2.3 & 1.26 \\
\hline 0 & fgf20 fin regeneration & 51571925 & 26 & 7.2 & - & - & 1.8 & 1.26 \\
\hline
\end{tabular}

Exp1, experiment 1. Exp2, experiment 2. Exp3, experiment 3. Spot $n^{\circ}$, number of spot selected in the 2 D gel of Exp1 (Figure 2) for mass spectrophotometry (MS) identification. 0 , numbers of spots selected in $2 \mathrm{D}$ gels of exp 2 or 3 (not shown). Gel spots were digested with trypsin and their peptides identified by MS. The corresponding detected proteins with a $100 \%$ of probability score of identification are shown grouped by their function. ${ }^{*}$, spots hypothetically identified by their apparent molecular weight (MW) and isoelectric point (IP) in their respective $2 \mathrm{D}$ gels. - , spots too faint to be quantified. $\sim \mathrm{MW}$ and $\sim \mathrm{PI}$, apparent molecular weight (MW) and isoelectric points (IP) in the $2 \mathrm{D}$ gel. Accession number of the identified protein sequences in the protein bank. Fold, calculated by the DeCyder-differential in-gel analysis software by the formula, volume of the spot in the VHSV-infected fin/volume of the spot in the non-infected fin. The spots on Figure 2 which have no corresponding description on Table 2 could not be identified by MS. Microarray differential expression data was obtained as explained in the legend of Table 3. Because most of the protein genes appeared several times in the microarray, their corresponding folds were calculated as the means for each of their data $(n=3-10)$. NF, not found annotated in the microarray.

microarray sequences, only those corresponding to the mhc1uaa and mhc1ze genes in fins (Table 3) were increased. However, most of their lower folds and p > 0.05 values resulted from their higher folds in only one of the experiments (data not shown).

Previously described up-regulated typical gene markers of viral infection-by-injection, il1b (interleukin $1 \beta,>2$ fold) or tnfa (tumor necrosis factor alpha, $>14$ fold) were found among the genes increased in fins or organs (Figure 4) but with $\mathrm{p}>0.05$.

Two different oligo sequences from the hepcidin antimicrobial peptide 1 (hamp1) gene detected similarly increased transcripts in the fins but not in organs (Table 3 and Figure 4).

Some of the 64 transcripts corresponding to immunoglobulin-related genes $(i g)$, specially those corresponding to the heavy chain gene, increased in the fins (ighv4-6, ighv1-2, ighv1-1 and ighv1-1zeta) (Table 3) and in the organs (ighv1-1 and ighz). Among the transcripts increased, those corresponding to the newly described immunoglobulin $\mathrm{Z}$, both at the fins (ighv1-1zeta) and at the organs (ighz) might be relevant to mucosal immunity as could be expected from a natural route of infection.

Figure 5B shows the comparison of fold levels between the transcripts that were differentially increased in both Q-PCR array and microarrays. Only $c 3 b, c 8$ (2 different subunits), c9, mhc1 (2 different genes), sid4, mst1 and $c d 36$ fin transcripts were increased in both Q-PCR array (Table 2) and microarray (Table 3).

\section{Discussion}

\section{Major protein changes at the fins after VHSV infection}

The differential expression (VHSV-infected versus noninfected) of fin proteins, identified their most abundant proteins with high variations among experiments (Table 1). Individual fish variation in the development of VHSV infection and on the different amounts of muscle sampled at the bases of the fins (10-20\%), different yields of the fin protein precipitation techniques and 2D-DIGE technical irreproducibility, all contributed to the wide quantitative differences. Nevertheless, some differential abundances of the major protein components could be detected.

For instance, most of the enzymes of the glycolytic pathway were differentially increased (Table 1). Similar enzymes were also found among the cDNA library genes from HRV-infected leukocytes of japanese flounder $[17,18]$. In contrast, no enzyme transcripts related to the glycolytic pathway increased in organs after HRV [19] or IHNV [20] infection-by-injection, nor in DNA vaccination-by-injection with the G gene of HRV [21], VHSV [22] or IHNV [23].

Many proteins classified and/or related to the cytoskeleton (actins, dynamin, semaphorin, myosin, etc), vesicle trafficking and/or fin regeneration (fgf20) [24] were differentially expressed (Table 1). At least some of those might reflect fin regeneration attempts to compensate for their destruction as VHSV infection progresses. Similar proteins were also found among the cDNA obtained from the HRV-infected leukocytes of the japanese flounder mentioned above [17].

Increases of hmgb1 protein levels (2.4-3.7-fold, Table 1) were detected in VHSV-infected fins. However, their transcript levels were unchanged (Table 1). Similarly, $h m g b 1$ transcript profiles after intramuscular injection of the IHNV G gene in trout showed that none of their 6 cDNAs microarray probes changed [23]. Nevertheless, transcripts of $h m g b 1$ were identified among the HRVinfected leukocytes of japanese flounder $[17,18]$ and a 1.9-fold increase of hmgb2-like 1 kidney transcripts was found in IHNV-infected trout (Dr. J.C. Balasch, personal communication) (MacKenzie et al., 2008). In mammalians, hmgbl is an abundant nuclear protein being secreted upon bacterial infections to enhance tissue repair, attract inflammatory cells, induce chemokines, and activate dendritic cells. All these properties make hmgb1 an important intermediate between innate and 
adaptative responses [25] and a vaccine adjuvant candidate [26]. Most recently, secreted $h m g b 1$ from dendritic cells was demonstrated during Dengue viral replication [27] and it has also been tested as a vaccine adjuvant $[28,29]$. The potential use of $h m g b 1$ as an adjuvant for fish vaccines, therefore, might deserve further attention.

The differential expression of some fin proteins (transferrin, hemopexin, annexin A5b, ATP binding, alpha actin, and kinesin) showed a parallel variation in their transcript levels (Table 1). However, in most of them, the protein differential expression changes did not correlate with their corresponding transcript changes, suggesting that regulation of their expression was not at the transcriptional level, at least in 2-day VHSV-infected fins. Although correlation of gene and protein expression levels have been found in some plants [30,31], most studies found no correlation, including a recent report on individual E. coli cells [32]. On the other hand, exclusive post-translational regulation of enzymes of the glycolytic pathway has been reported [33], which could explain some of the data found here. Although, similar studies are still scarce, correlation values comparing gene/protein expression levels in several systems were very low [34], and varied with the protein relative abundance and their half-life time. Most correlation values showed that mRNA might be a poor indicator of protein expression. Study of mRNA levels, is justified when there is no other way to study gene expression levels, as in the present case where the VHSV immune-related proteins cannot be detected by the proteomic approach.

\section{Transcript level changes of immune-related genes at the} fins and organs after VHSV infection

The number of the 186 immune-related transcripts differentially increased were higher in fins than in organs as estimated by Q-PCR. Similar results were obtained with the 636 immune-related transcripts estimated by microarray hybridization. In contrast, the number of

Table 2 Differential expression of transcripts from fins and organs by Q-PCR arrays

\begin{tabular}{|c|c|c|c|c|}
\hline \multirow[b]{2}{*}{ accession number } & \multirow[b]{2}{*}{ shortname } & \multirow[b]{2}{*}{ long name transcripts } & \multicolumn{2}{|l|}{ fold } \\
\hline & & & Fins & Organs \\
\hline \multicolumn{5}{|c|}{ complement components } \\
\hline NM_001024435 & c9 & complement component 9 & 15.33 & 2.71 \\
\hline NM_131243 & $c 3 b$ & complement component c3b & 9.24 & -1.30 \\
\hline NM_200863 & $c 8 g$ & complement component 8. gamma polypeptide & 3.69 & 1.63 \\
\hline \multicolumn{5}{|c|}{ immunoglobulin-related proteins } \\
\hline NM_001034182 & sid4 & secreted immunoglobulin domain 4 & 35.99 & 1.09 \\
\hline \multicolumn{5}{|c|}{ cluster differentiation antigens } \\
\hline NM_001002363 & $c d 36$ & CD36 antigen & 7.68 & 1.26 \\
\hline NM_212619 & $c d 9$ & CD9 antigen (p24) & 2.09 & 1.25 \\
\hline \multicolumn{5}{|l|}{ interleukins } \\
\hline NM_001020792 & $i \mid 22$ & interleukin 22 & 3.59 & -1.32 \\
\hline NM_001020789 & $i l 17 d$ & interleukin $17 d$ & 2.20 & 1.04 \\
\hline \multicolumn{5}{|c|}{ major hystocompatibility complex } \\
\hline NM_131471 & mhcluba & major histocompatibility complex class I UBA gene & 3.01 & 1.41 \\
\hline \multicolumn{5}{|c|}{ guanine nucleotide binding proteins } \\
\hline NM_213224 & $g n / 2$ & guanine nucleotide binding protein-like 2 (nucleolar) & 2.72 & -1.09 \\
\hline NM_001002397 & gng7 & guanine nucleotide binding protein gamma 7 & 2.02 & 1.21 \\
\hline \multicolumn{5}{|l|}{ Various } \\
\hline NM_152980 & mst1 & macrophage stimulating 1 hepatocyte growth factor & 25.02 & -1.36 \\
\hline NM_131607 & tradd & tnfrsf1a-associated via death domain & 2.83 & 1.07 \\
\hline NM_001110278 & acvr2a & activin receptor lla & 2.49 & -1.01 \\
\hline NM_001039637 & foxp 16 & forkhead box P1b & 2.37 & 1.09 \\
\hline NM_200154 & sla/lpl & soluble liver antigen/liver pancreas antigen. like & 2.28 & 2.10 \\
\hline NM_131000 & alcam & activated leukocyte cell adhesion molecule & 2.25 & -1.29 \\
\hline NM_001040353 & crfb 12 & cytokine receptor family member B12 & 1.68 & -3.33 \\
\hline
\end{tabular}

For each experiment, 10 zebrafish were infected with $2 \times 10^{6} \mathrm{ffu}$ of $\mathrm{VHSV} / \mathrm{ml}$ at $14^{\circ} \mathrm{C}$ while other 10 zebrafish remained non-infected. RNA was extracted from the fins or organs 2-days after VHSV or mock infection, converted to cDNA and used for the AmpliTaq reaction in 384 well plates containing $2 \times 186$ selected immune-related zebrafish TaqMan Assays (Applied Biosystems). In each plate, $2 \times 3$ assays of the $r p l p 0$ gene were used for normalization. The mean and their corresponding $\mathrm{p}$ (t Student one tail) were then calculated from 5 experiments. The transcripts from either fins and/or organs with $>2$-fold and $\mathrm{p}<0.05$ changes were first tabulated and then the rest of the table was completed with their corresponding calculated fold values in organs and/or fins, respectively. Fold, expression level in VHSV-infected tissue/expression level in non-infected tissue. +, increased. -, decreased. , similar. Figure 3 shows the representation of means and standard errors (SE) of all the genes. 


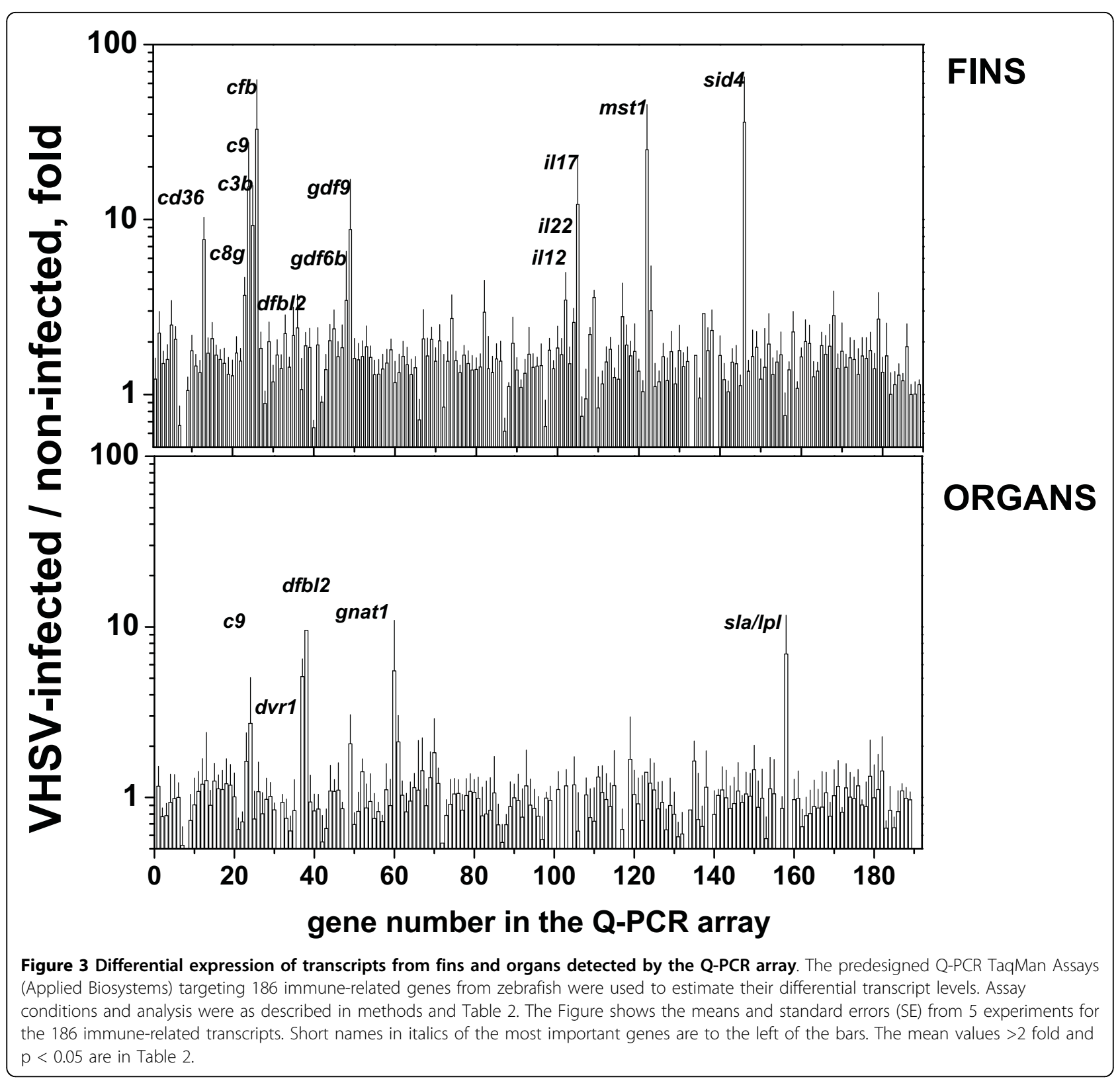

differentially decreased transcripts were higher in organs than in fins (Figure 5A). It seems likely that 2-days after infection-by-immersion, VHSV has not yet caused an increased differential response from the internal organs, contrary to what has been described for infection-byinjection in other fish models [17-23,35-40]. The lower numbers of increased transcripts seen in organs compared to fins may be due to a delay in virus tissue infiltration. Thus, the reason for the major differences seen in transcription may be solely because 51.4-fold more VHSV was present in fins than in organs. However, if the decreases in transcription are due to the virus, one would expect to see the most significant decreases in fins where the VHSV is more abundant. As an alternative explanation, transcriptions in organs could be inhibited by some soluble viral protein(s) released from the infected fish surfaces. There are not yet any evidences to decide for an explanation of these data.

The differential increased expression obtained in fins indicate that zebrafish responses are not fully immunocompromised at low temperatures. Low external and therefore low body temperatures in zebrafish can be immunosuppressive, as it has been supported by numerous studies. However, most of those studies demonstrate a delay or inhibition of adaptative immune responses, while at least some innate defenses were increased until 
the specific immune system adapted [13,41,42]. Thus, cold acclimatized zebrafish fins increased the expression of proteins and transcripts of some immune-related genes after VHSV infection (Tables 1, 2 and 3), confirming some previous results on rhabdoviral vaccinated zebrafish [8]. However, under the conditions used, most of the organ early responses previously described in infection-by-injection models could not be detected in fins ( $m x, t n f a, i l 8$, ifn, etc) [17-23,39,40], although some of them (i.e. tnfa) were detected in organs (Table 3 and Figure 4). On the other hand, because VHSV [8] or spring viremia carp virus SVCV $[12,14]$ maximal mortalities only occurred at lower than physiological temperatures, there is no other way to study gene responses to rhabdoviral infections. High mortalities at low temperatures could be explained by a more rapid VHSV replication rate in comparison with slower zebrafish defenses, such as it was suggested in the zebrafish/SVCV model [12]. Comparison of the gene expressions between zebrafish/VHSV and zebrafish/SVCV models might help to identify new genes, since while mortalities are maximal at similar temperatures $\left(12-14^{\circ} \mathrm{C}\right)$ [14], optimal SVCV in vitro replication occurs at $20-22^{\circ} \mathrm{C}$ which is closer to the zebrafish optimal temperature. Because zebrafish without cold acclimatation was refractory to infection-byimmersion with IHNV [10], VHSV [8] or even with SVCV [12], there must exist some temperature-dependent host response mechanism(s) that inhibits rhabdoviral infection and/or their spreading. This temperaturedependence might be of interest for further studies.

Figure 5B shows the fin transcripts increased with $>2$ fold and p $<0.05$ in both Q-PCR (Table 2) and oligo microarrays (Table 3 ). Only complement components $(c 3 b, c 8$ and $c 9)$, class I histocompatibility antigens (mhc1), secreted immunoglobulin domain (sid4), macrophage stimulating factor (mst 1 ) and a cluster differentiation antigen ( $c d 36)$ were detected in both arrays under those conditions. Transcripts related to the complement pathway $(c 3 b)$ and their corresponding terminal lysiscomplex genes ( $c 8$ and $c 9$ ) [43], were also found in ESTs from HRV-infected leukocytes of japanese flounder [17]. However, many more complement-related genes which were not present in the Q-PCR array, were detected by the oligo microarray data $(c 3 b, c 3$ precursor, $c 9, c f b, c f b / c 2 b, c 8 a, c r p p, c f h p$ and $c 6$ ) (Table 3), suggesting that complement components are one of the first lines of defense induced in VHSV-infected fins. In this respect, earlier studies failed to demonstrate a possible relation of trout $c 3$ genetic polymorphisms to VHSV resistance [44]. On the other hand, although some reports do exist on exploration of $c 3 a, c 3 d, c 4 a$ and $c 5 a$ [45] as vaccine adjuvants in mammals, they remain unexplored in fish. With respect to $m h c$ genes, most class I antigens represented in the microarray remained unchanged although high variations among experiments were detected in most genes and a few of them in either fins or organs changed (Tables 2 and 3). At least some $m h c$ genes also remained unchanged in trout after IHNV infection-by-injection [46]. The secreted immunoglobulin 4 (sid4) of the immunoglobulin superfamily [47] and the macrophage stimulating factor (mst1) [48] have been scarcely studied. In mammalians, $c d 36$ is restricted to platelets, monocytes, B-cells, macrophages, keratinocytes, epithelial and endothelial cells. On macrophages, $c d 36$ is involved in phagocytic clearance of apoptotic cells [49].

Increased il12 transcripts with $>2$-fold but $\mathrm{p}>0.05$, were found in the fins by both arrays while they were inhibited in organs (not shown). Il12 is produced in mammalian macrophages, monocytes, dendritic cells and B lymphocytes in response to intracellular pathogens. Il12 stimulates $t n f a$, but no induction of $\operatorname{tnfa}$ was observed in fins despite of the presence of induced expression levels of Il12. Nevertheless, $\operatorname{tnfa}$ was the most increased transcript in organs according to the oligo microarray data (Figure 3) but with $\mathrm{p}>0.05$. Il12 has been abundantly described as a viral vaccine adjuvant to increase protective mucosal immunity [50]. It has not been tested in fish.

Other transcripts only appeared differentially expressed in one of the arrays, such as $i l 17 d$ and $i l 22$ (Table 2). Both $i l 17$ and $i l 22$ are produced by $\mathrm{T}$ helper 17 (Th17) cells [51] to synergistically induce antimicrobial peptides [52] in human keratinocytes [53]. At this respect, 2 antimicrobial peptides increased in VHSVinfected zebrafish fins and organs, including the hepcidin antimicrobial peptide 1 (hamp1) and the $\beta$ defensin (defbl2) genes, the former one with $\mathrm{p}>0.05$. Increased hamp 1 had also been detected in turbot by microarray analysis of bacterial [54] and nodavirus [55] infections and in stimulated RTS11 trout macrophage cell line [56]. Since, previous findings also implicated defbl2 in both rhabdoviral blocking and activation of trout immune defense genes [57], these 2 antimicrobial peptides might deserve further studies.

\section{Conclusions}

VHSV, IHNV and SVCV natural infections with maximal mortalities occur in salmonids and/or carp after low or changing temperatures in the spring and/or autumn. The results described here demonstrate that, at least zebrafish are not fully immunocompromised at low temperatures. Increased fin transcript levels detected by both Q-PCR and hybridization arrays corresponded to previously described infection-related genes such as complement components ( $c 3 b, c 8$ and $c 9$ ) or class I histocompatibility antigens $(m h c 1)$ and to newly described genes such as secreted immunoglobulin domain (sid4), 
Table 3 Differential expression of transcripts from fins and organs by hybridization to the oligo microarray

\begin{tabular}{|c|c|c|c|c|}
\hline \multirow[b]{2}{*}{ accession number } & \multirow[b]{2}{*}{ short name } & \multirow[b]{2}{*}{ long name transcripts } & \multicolumn{2}{|c|}{ fold } \\
\hline & & & Fins & $\overline{\text { Organs }}$ \\
\hline \multicolumn{5}{|c|}{ complement components } \\
\hline NM_131243 & $c 3 b$ & complement component c3b & 8.37 & -1.21 \\
\hline P01024 & $c 3$ & complement c3 precursor & 6.63 & 1.81 \\
\hline NM_001024435 & $c 9$ & complement component 9 & 5.95 & 1.46 \\
\hline TC319537 & c9 & complement component 9 & 5.85 & 3.33 \\
\hline TC360850 & c9 & complement component 9 & 5.83 & 1.75 \\
\hline NM_131338 & $c f b$ & complement factor $b$ & 5.60 & 1.00 \\
\hline XR_029814 & $c f b / c 2 b$ & $\sim$ to complement factor b/c2b & 5.14 & -1.27 \\
\hline NM_001003496 & $c 8 a$ & complement component 8, alpha polypeptide & 4.94 & -1.26 \\
\hline NM_200863 & $c 8 g$ & complement component 8 gamma polypeptide & 1.41 & -4.34 \\
\hline TC331566 & crpp & complement regulatory plasma protein & 4.74 & -1.11 \\
\hline XM_0013357 & chp & $\sim$ to complement factor $h$ precursor & 3.96 & 1.02 \\
\hline NM_200638 & $c 6$ & complement component 6 & 2.22 & 1.11 \\
\hline XM_692828 & perf & $\sim$ to perforin & -1.78 & 2.93 \\
\hline \multicolumn{5}{|c|}{ immunoglobulin-related proteins } \\
\hline AY494978 & sid4 & secreted immunoglobulin 4 precursor & 5.68 & 1.18 \\
\hline NM_001034182 & sid4 & secreted immunoglobulin domain 4 & 5.30 & 1.26 \\
\hline AF273876 & ighv4-6 & VH101 immunoglobulin heavy chain variable region & 2.57 & 1.33 \\
\hline AF273880 & ighv1-2 & VH1 14 immunoglobulin heavy chain variable region & 2.42 & 1.96 \\
\hline AF273901 & ighv1-1 & VHcd9 immunoglobulin heavy chain variable region & 2.08 & 3.63 \\
\hline AY646264 & ighv1-1 & immunoglobulin zeta heavy chain & 2.29 & 1.21 \\
\hline AY643752 & $i g h z$ & immunoglobulin Z heavy chain constant region & 1.35 & 2.02 \\
\hline XM_690081 & iefr & $\sim$ to immunoglobulin epsilon Fc receptor lgE & 2.64 & -1.56 \\
\hline XM_001920109 & pirp & $\sim$ to Polymeric immunoglobulin receptor precursor & 2.33 & 1.22 \\
\hline NM_001145630 & Irit3 & leucine-rich repeat lg-like and transmembrane domains 3 & -2.85 & -3.25 \\
\hline XM_001919777 & npcid & containing immunoglobulin domains & 5.07 & -2.07 \\
\hline \multicolumn{5}{|c|}{ cluster differentiation antigens } \\
\hline NM_001002572 & $c d 36$ & CD36 antigen & 6.12 & -11.11 \\
\hline Q3U490 & $c d 11 c$ & CD11c dendritic cells & 2.53 & -1.05 \\
\hline \multicolumn{5}{|l|}{ macrophages } \\
\hline NM_152980 & mst1 & macrophage stimulating 1 hepatocyte growth factor & 6.42 & 1.20 \\
\hline NM_152980 & mst1 & macrophage stimulating 1 hepatocyte growth factor & 5.54 & 1.08 \\
\hline NM_001113641 & mict & $\sim$ to macrophage-inducible C-type lectin & 4.93 & 1.23 \\
\hline \multicolumn{5}{|l|}{ interleukins } \\
\hline Q494Q4 & $i / 11 b$ & interleukin-11b. & 4.27 & 2.88 \\
\hline NP_998009 & $i / 1 b$ & interleukin 1, beta & 2.36 & 1.37 \\
\hline NM_001020789 & $i / 17 d$ & interleukin 17d & -2.27 & -4.85 \\
\hline NM_001018118 & il151 & interleukin 15 like (il15l) transcript variant 2 & -1.07 & -2.44 \\
\hline NM_001007108 & il12ba & interleukin 12Ba natural killer cell stimulatory factor 2 & 1.53 & -25.70 \\
\hline NM_153660 & il17rd & interleukin 17 receptor D & 1.04 & -1.45 \\
\hline \multicolumn{5}{|l|}{ tolls \& receptors } \\
\hline Q6TQH6 & $\operatorname{tr} 7$ & toll-like receptor 7 & 4.09 & 1.22 \\
\hline AY389449 & $\operatorname{tr} 5 a$ & toll-like receptor $5 a$ & 2.03 & 1.28 \\
\hline NM_001130594 & $\operatorname{trg}$ & toll-like receptor 9 & 1.05 & -2.29 \\
\hline NM_131010 & $t / 11$ & tolloid-like 1 & -1.72 & 2.82 \\
\hline NM_001113602 & crlfib & cytokine receptor-like factor $1 \mathrm{~b}$ & -1.72 & -2.90 \\
\hline NM_200600 & traf3ip1 & TNF receptor-associated factor 3 interacting protein 1 & 1.19 & -2.51 \\
\hline XM_001334668 & traf & $\sim$ to TRAF and TNF receptor-associated homolog & -1.61 & -2.00 \\
\hline
\end{tabular}




\begin{tabular}{|c|c|c|c|c|}
\hline \multicolumn{5}{|c|}{ major hystocompatibility complex } \\
\hline Z46776 & mhcluaa & UAA class I MHC & 3.92 & -23.6 \\
\hline AJ420954 & mhcize & MHC class I antigen & 2.16 & 1.44 \\
\hline NM_001045563 & $m h c 1 d z 63$ & novel MHC class I antigen dZ63M10.3 & -1.14 & -2.84 \\
\hline \multicolumn{5}{|c|}{ antimicrobial peptides } \\
\hline NM_205583 & hamp1 & hepcidin antimicrobial peptide 1 & 10.91 & -1.04 \\
\hline NM_205583 & hamp1 & hepcidin antimicrobial peptide 1 & 9.63 & -1.05 \\
\hline \multicolumn{5}{|l|}{ interferons } \\
\hline NM_001111083 & ifn3 & interferon 3 & 2.13 & -1.08 \\
\hline XM_001344345 & gig2 & to interferon-inducible protein Gig2 & 2.57 & -2.18 \\
\hline Q1LV7 & ifi44 & $\sim$ to vertebrate interferon-induced protein 44 & 1.16 & -3.30 \\
\hline \multicolumn{5}{|l|}{ Lymphocytes } \\
\hline Q5RI69 & sell & $\sim$ to vertebrate selectin $L$ (Lymphocyte adhesion mol 1) & 1.48 & 3.33 \\
\hline NM_131426 & lef1 & lymphocyte enhancer binding factor 1 & -1.35 & -5.71 \\
\hline A1L4S5 & ctlp4 & cytotoxic T-lymphocyte protein 4. & -1.96 & -3.26 \\
\hline XM_001340972 & prf1 & to Perforin-1 precursor (Lymphocyte pore-forming) & -1.33 & -3.07 \\
\hline NM_001126448 & lect1 & leukocyte cell derived chemotaxin 1 & 1.11 & -2.83 \\
\hline Q5RJ36 & Ink & $\sim$ vertebrate lymphocyte adaptor protein & -1.08 & -2.05 \\
\hline \multicolumn{5}{|l|}{ Various } \\
\hline XM_001336492 & sica21 & to small inducible cytokine A21 & -1.04 & -3.43 \\
\hline NM_001030118 & sart3 & squamous cell carcinoma antigen recognised by $T$ cells 3 & 0.96 & -3.39 \\
\hline NM_001030118 & sart3 & squamous cell carcinoma antigen recognised by T cells 3 & 1.13 & -2.97 \\
\hline
\end{tabular}

For each experiment, 10 zebrafish were infected with $2 \times 10^{6} \mathrm{ffu}$ of VHSV/ml at $14^{\circ} \mathrm{C}$ while other 10 zebrafish remained non-infected. RNA was extracted from the fins or organs 2-days after VHSV or mock infection, labeled with Cy3 and hybridized to the microarrays. The 636 immune-related selected sequences from the $4 \times 44 \mathrm{~K}$ microarray (Appligene) from zebrafish were selected and their data analyzed. In each microarray, 4 assays of $r p / p 0$ gene were used for normalization. The mean and $\mathrm{p}$ (t Student one tail) were then calculated from 4 experiments. The transcripts from either fins and/or organs with $>2$-fold and $p<0.05$ changes were first tabulated and then the rest of the table was completed with their corresponding calculated fold values in organs and/or fins, respectively. Fold, expression level in VHSV-infected tissue/expression level in non-infected tissue. +, increased. -, decreased. $\sim$, similar. Figure 4 shows the representation of the means of all the immune-related genes.

macrophage stimulating factor (mst 1 ) and a cluster differentiation antigen $(c d 36)$. The genes described would contribute to the knowledge of the earliest molecular events occurring in the fish surface tissues at the beginning of natural rhabdoviral infections and/or might be new candidates to be tested as molecular adjuvants for fish vaccines.

\section{Methods}

Viruses and cell culture

The VHSV 07.71 isolated in France from rainbow trout Onchorynchus mykiss (Walbaum) was grown in the Epithelioma papulosum cyprini (EPC) cells obtained from the ATCC collection (CRL-2872), recently identified as belonging to fathead minnow (Pimephales promelas). They were grown in $25 \mathrm{~cm}^{2}$ flasks at $28^{\circ} \mathrm{C}$ in RPMI Dutch modified cell culture medium buffered with $20 \mathrm{mM}$ HEPES (Flow) and supplemented with 10\% fetal calf serum, $1 \mathrm{mM}$ piruvate, $2 \mathrm{mM}$ glutamine, 50 $\mu \mathrm{g} / \mathrm{ml}$ of gentamicin and $2.5 \mu \mathrm{g} / \mathrm{ml}$ of fungizone. To prepare VHSV for in vivo challenges and to assay for VHSV infectivity, the cell culture media was the same as above except for the inclusion of $2 \%$ fetal calf serum and $10 \mathrm{mM}$ Tris $\mathrm{pH}$ 8.0. The VHSV was assayed by immunodetection of infected foci in EPC cell monolayers as described before [58].

\section{Zebrafish infection with VHSV and tissue harvest}

Adult zebrafish of $2-3 \mathrm{~g}(\sim 4 \mathrm{~cm}$ in length) were obtained from a local fish pet shop to study a situation that more closely resembles the variability of natural populations. Zebrafish were maintained at $24-26^{\circ} \mathrm{C}$ in 30 $\mathrm{l}$ aquaria with tap-dechlorinated carbon-filtered water with $1 \mathrm{~g}$ of $\mathrm{CaCl}_{2}, 1 \mathrm{~g}$ of $\mathrm{NaHCO}_{3}$ and $0.5 \mathrm{~g}$ of Instant Ocean sea salts added to water resulting in a conductivity of 200-300 $\mu \mathrm{S} \mathrm{pH}$ of 7.8-8.2. The aquaria were provided with biological filters and fish fed with a commercial feed diet. For each experiment, groups of 10 adult zebrafish were moved to $2 \mathrm{l}$ aquaria provided with biological filters at $14^{\circ} \mathrm{C}$ for cold acclimatation. After 7 days, groups of 10 zebrafish were infected-by-immersion in $2 \times 10^{6} \mathrm{ffu}$ of VHSV per $\mathrm{ml}$ at $14^{\circ} \mathrm{C}$ during $2 \mathrm{~h}$ in 50 $\mathrm{ml}$ aerated bottles filled with aquarium water. Zebrafish were then released to the $2 \mathrm{l}$ aquaria and maintained during 2-days at $14^{\circ} \mathrm{C}$. After decapitation, blood was collected in $100 \mu \mathrm{l}$ of sterilized anti-coagulation medium ( $0.64 \mathrm{~g}$ of sodium citrate, $0.15 \mathrm{~g}$ of EDTA and $0.9 \mathrm{~g}$ of sodium chloride in $100 \mathrm{ml}$ of distilled water) per fish, 


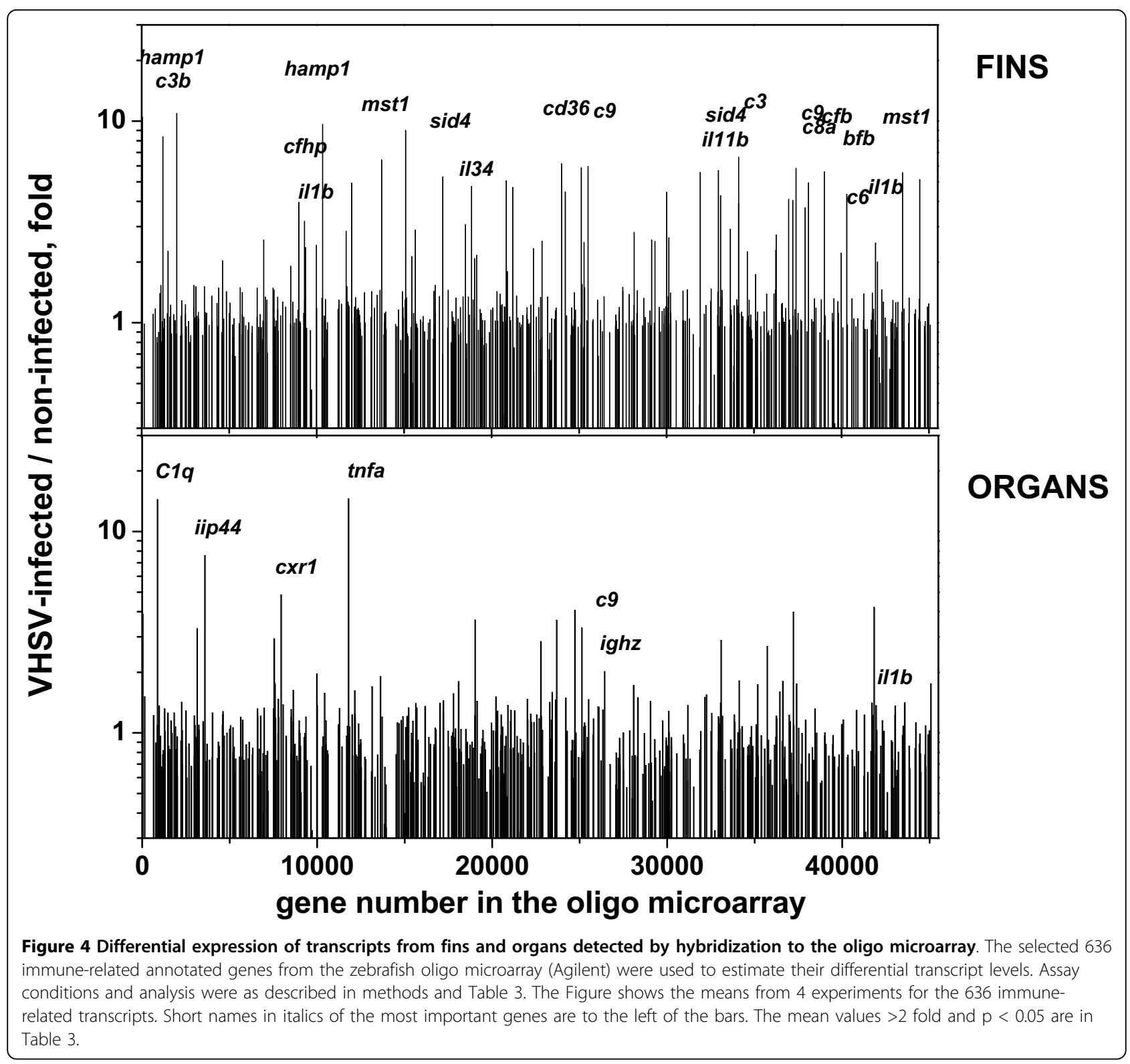

then pooled and centrifuged to obtain $1 / 10-1 / 20$ diluted plasma (as evaluated by nanodrop absorbance at 280 $\mathrm{nm}$ ). Fins (dorsal, ventral and caudal) or organs (spleen, head kidney and liver) were harvested and separately pooled from each group of 10 fish to obtain enough protein and RNA to analyze the data. By visual inspection, a $10-20 \%$ of muscle tissue was included in the fin samples. The fins or organs were immersed in RNAlater (Ambion, Austin, USA ) at $4^{\circ} \mathrm{C}$ overnight before being frozen at $-70^{\circ} \mathrm{C}$ until processed. Experimental protocols were performed with the approval of the Departamento Biotecnologia (INIA) and the Instituto de Investigaciones Marinas (CSIC) corresponding ethic committees.
Sample preparation and labeling with cyanine dyes for two dimensional (2D) differential gel electrophoresis (DIGE)

Fins pooled from 10 zebrafish were sonicated (Braunsonic 300S) in $1 \mathrm{ml}$ of RTL buffer (RNeasy kits from Qiagen, Hilden, Germany) at 10W 1-2 min on ice. The homogenate diluted 3-fold with cold acetone was centrifuged $15 \mathrm{~min}$ at $12.000 \mathrm{~g}$. Protein pellets were dissolved in water, sonicated and centrifuged again. Water insoluble pellets were discarded and aqueous extract protein concentrations were estimated by the BCA micro protein assay kit (Pierce, Rockford, IL, USA), by nanodrop ND1000 spectrophotometer (Nanodrop Technologies 

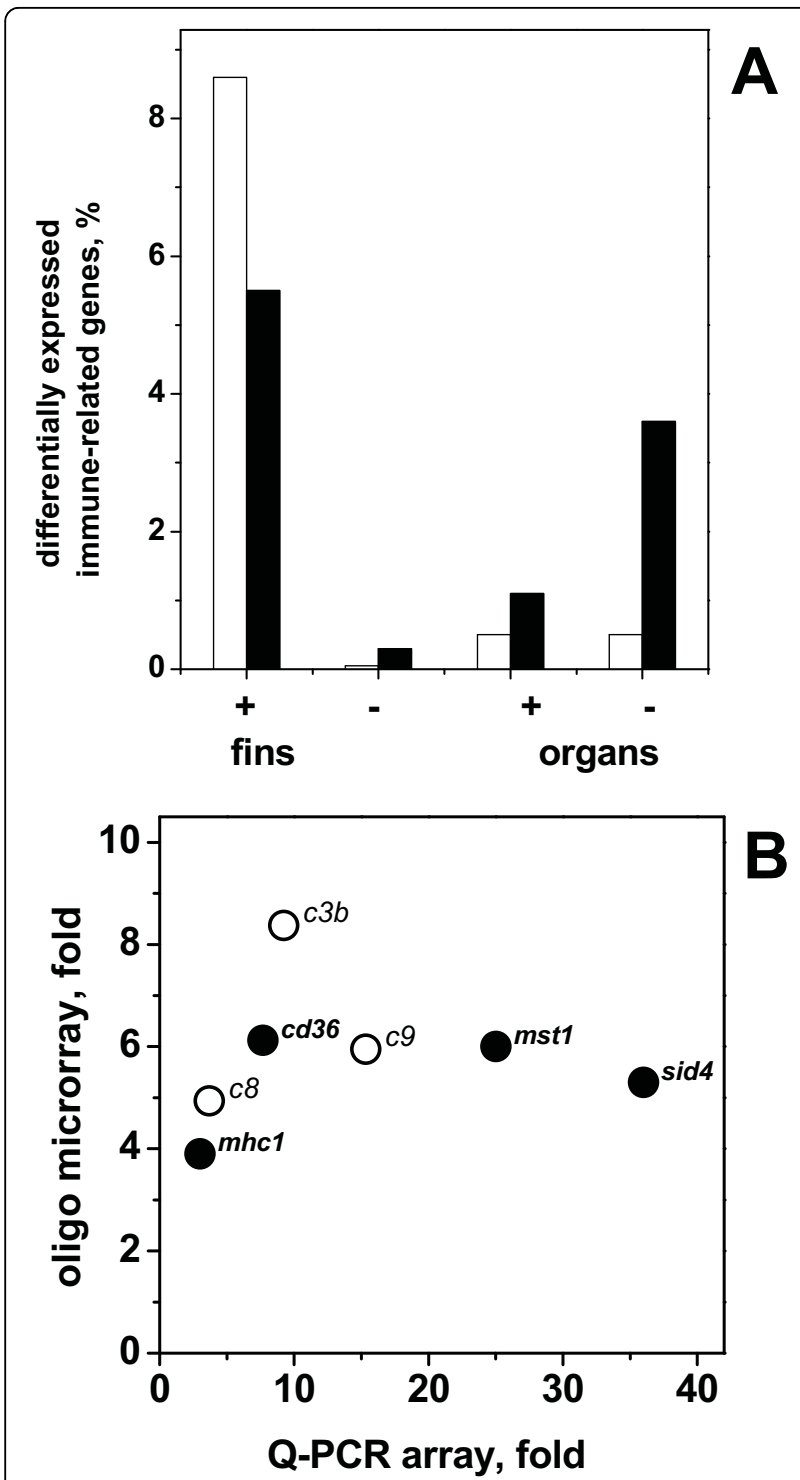

Figure 5 Total numbers of differentially expressed genes from fins and organs detected by Q-PCR and oligo microarrays (A) and differentially increased fin genes by both Q-PCR and oligo microarrays (B). A) Represents the total number of genes

increasing $>2$-fold with $p<0.05$ (Tables 2 and 3 ) as the percentage of the total number of immune-related genes assayed in Q-PCR (open bars) or oligo microarrays (black bars). Percentages were calculated by the formula, $100 \times$ number of differentially expressed genes/total number of immune-related genes assayed. +, increasing after VHSV infection. -, decreasing after VHSV infection. B) Represents the differential fin transcript levels together with their gene short names that increased $>2$-fold and $p<0.05$ in both Q-PCR and oligo microarrays.

Inc, Wilmington, DE, USA) and confirmed by polyacrylamide gel electrophoresis for accurate normalization.

Thirty micrograms of protein from VHSV-infected and non-infected fins were separately labeled (Appplied Biomics, Hayward, CA, USA) with fluorescent Cy3 and
Cy5, respectively (Amersham Biosciences, Inc. Piscataway, NJ, USA) and then pooled. The first dimension of the 2D-DIGE used an immobilized $\mathrm{pH}$ gradient gel (Amersham Biosciences, GE Healthcare N.J.). After second dimension SDS-PAGE, the gel was scanned using the Typhoon Trio scanner and images analyzed with ImageQuant software (Amersham Biosciences). Quantification of protein expression was carried out by DeCyder-differential in-gel analysis software (Applied Biomics, Hayward, CA, USA). Protein spots with $>2$-fold change between VHSV-infected and non-infected fin extracts were excised from preparative gels $(\sim 300 \mu \mathrm{g}$ of protein) by using an Ettan spot picker (Amersham Biosciences) and digested with trypsin.

The trypsin-digested peptides were used for MALDITOF protein identification (MALDI-TOF/TOF mass spectrophotometer, ABI-4700 from Applied Biosystems, Inc, Foster City, CA, USA). By using the Mascot search engine (Matrix Science, Boston, MA, USA), the National Center for Biotechnology (NCBI)/SwissProt protein data bases were searched for $>95 \%$ matches of high quality mass spectra.

Quantification of the VHSV N protein mRNA levels by RTQ-PCR

The primers 5'-TCAAGGTGACACAGGCAGTCA (sense), 5'-CCAGTTCTCTCATGGGCATCAT (antisense) and 5'-CCACGAGCATCGAGGCGGGAAT (labeled with 6-carboxyfluorescein, FAM and 6-carboxytetrametil-rodamine, TAMRA) were used to detect VHSV $\mathrm{N}$ transcript by quantitative reverse transcriptase polymerase chain reaction (RT-Q-PCR) as described before [59]. Briefly, $50 \mathrm{pg}$ of each primer and the labeled probe were added to cDNA obtained from $25 \mathrm{ng}$ of RNA from VHSV concentrated from VHSV-infected EPC cell cultures (reference curve made from $10^{10} \mathrm{ffu}$ of VHSV per $\mathrm{ml}$ ), and zebrafish fins or organ extracts. Then, 4 units of Ampli-Taq polymerase (Perkin-Elmer, Weiterstadt, Germany), buffer and water to $100 \mu \mathrm{l}$ were added and the mixtures heated to $50^{\circ} \mathrm{C}$ for $2 \mathrm{~min}$, denatured at $95^{\circ} \mathrm{C} 10 \mathrm{~min}$ and then amplified by 45 cycles of 15 seconds at $95^{\circ} \mathrm{C}$ and $1 \mathrm{~min}$ at $60^{\circ} \mathrm{C}$. The products were analyzed in a Rotor-gene 2000 machine (RCorbett Research, Sydney, Australia ). The abundance of the corresponding mRNA was calculated from the cycle threshold $(\mathrm{Ct})$ data in 3 different experiments, 10 zebrafish per experiment each by duplicate.

\section{Selection of zebrafish immune-related genes from Applied Biosystems (Q-PCR) array}

The 2008 latest collection of pre-designed, real time PCR assays in the TaqMan ${ }^{\circledR}$ Assays (Applied Biosystems) targeting 49826 sequences of zebrafish https://products. appliedbiosystems.com was searched for immune-related 
gene keywords: interferon, chemokine, interleukin, cytokine, defensin, macrophage, lymphocyte, antimicrobial, neutrophil, leukocyte, cytotoxic, natural killer, antiviral, antibacterial, LPS, Vig, antigen, cd* antigen, histocompatibility, phagocyte, viral, $\mathrm{Mx}$, complement, immunoglobulin, hepcidin, IgG, IgM, Toll, T cell, B cell, dendritic, presenting, TANK, GNB, HMGB, TNF and $\mathrm{MHC}$. All the entries retrieved were incorporated into an unique archive, duplicates eliminated, primers-probe spanning an exon junction (_m1) selected and the resulting gene list sent to the TaqMan custom plating service. A total of 186 immune-related genes were included into a 384 well plate $(2 \times 192$ sequences per plate) (GEO platform number GPL9804). Three sets from the ribosomal protein large P0 ( $r p l p 0)$ gene (Dr03131549_m1, Dr03131547_g1 and Dr03131546_m1, corresponding to the gene accession number NM_131580.1) were included for normalization purposes as used before [23].

\section{Quantitative estimation of zebrafish transcripts for selected immune-related $\mathbf{1 8 6}$ gene arrays by Q-PCR} RNA was extracted from sonicated $(1 \mathrm{~min} \times 3$ times at $40 \mathrm{~W}$ in ice) zebrafish fins or organs (pooled spleen, head kidney and liver) in RTL buffer (RNeasy kits, Qiagen, Hilden, Germany). RNA concentrations were estimated by nanodrop and the presence of 18 and $28 \mathrm{~S}$ bands confirmed by denaturing RNA agar electrophoresis (Sigma, Che.Co, MS, USA). Three $\mu$ g of RNA were immediately converted to cDNA by using the High Capacity RNA-to-cDNA Master mix (Applied Biosystems) by $30 \mathrm{~min}$ at $42^{\circ} \mathrm{C}$. One ng of cDNA was mixed with $\mathrm{TaqMan}^{\oplus}$ gene expression assays in a $10 \mu \mathrm{l}$ final volume and heated to $50^{\circ} \mathrm{C} 2 \mathrm{~min}$ (UDG decontaminating step), heat denatured $\left(95^{\circ} \mathrm{C} 10 \mathrm{~min}\right)$ and amplified by 35 cycles of $95^{\circ} \mathrm{C} 15$ seconds and $60^{\circ} \mathrm{C} 1 \mathrm{~min}$ in a $7900 \mathrm{H}$ Applied Biosystems machine in the FAM channel $(470 / 510 \mathrm{~nm})$. By using 3 TaqMan assays (hmgb1, gnb1 and rplp0) the amplification conditions were first adjusted to obtain lineal amplifications between 0.01 to 100 ng of RNA (data not shown). Each experiment containing VHSV-infected and non-infected samples was RT-Q-PCR amplified independently during a 5 month period. For each experiment, the relative number of molecules were calculated from the cycle threshold $(\mathrm{Ct})$ data by using the $2^{\text {-deltadelta }}$ relative quantitation method. Raw Ct were normalized for each experiment http:// www.ncbi.nlm.nih.gov/geo/query/acc.cgi?acc=GSE19503 by using the rplpO gene [23] according to the formula $\mathrm{Ct}$ gene - mean $\mathrm{Ct}$ of rplpo $(\mathrm{n}=3)$. Fold for each experiment was then calculated by the $2^{\text {-(Ct VHSV-infected- }}$ $\mathrm{Ct}$ non-infected) formula and means and standard errors calculated $(n=5)$. The $\mathrm{p}$ values corresponding to the hypothesis of VHSV-infected > non-infected were calculated by the one tail t-Student test. Outliers (significant results only in one experiment) were identified and eliminated from the calculations manually. Calculations were made by two independent researchers using Microsoft Excel, Origin pro vs 8.0 SR4 (Northampton, USA) and BRB-Array Tools http://linus.nci.nih.gov/BRBArrayTools.html. Their results were confronted until all discrepancies were solved.

\section{Quantitation of zebrafish immune-related transcripts by hybridization to oligo microarray}

The $4 \times 44 \mathrm{~K}$ format zebrafish 60 -mer oligo microarray (zebrafish vs2, ID019161) containing 43803 sequences was obtained from Agilent http://www.chem.agilent. com/en-US/pages/homepage.aspx. Some sequences (40-50\%) still contained preliminarily accession numbers while $\sim 10 \%$ of their sequences remained unknown at September 2009. Current microarray annotations were searched with the same keywords used for the Q-PCR arrays described above to identify 636 immune-related sequences. Each microarray contained 4 sequences of the $r p l p 0$ gene that were used for normalization purposes [23]. A total of 16 microarrays grouped in four $4 \times 44 \mathrm{~K}$ slides $(2$ slides for fins and 2 for organs, each containing 2 VHSV-infected and 2 non-infected samples) were used. RNA was kept frozen at $-80^{\circ} \mathrm{C}$ until all the experiments were hybridized and processed simultaneously. Labeling of $2 \mu \mathrm{g}$ of RNA $(\sim 50 \mu \mathrm{g} / \mathrm{ml})$ and hybridization to the microarrays were performed by the University of Santiago de Compostela at Lugo, Dpt. of Genetics, Spain (Dr.P.Martinez Portela) as described before [54], complying with the Minimum Information About a Microarray Experiment (MIAME) standards. Briefly, high quality RNA were labeled with Cy3 (Amersham Pharmacia) by using SuperScript III reverse transcriptase (InVitroGen) and oligo(dT) primer, and the resulting cDNA was purified with Microcon YM30 (Millipore). The slides were pre-treated with $1 \% \mathrm{BSA}$, fraction V, $5 \times \mathrm{SSC}, 0.1 \% \operatorname{SDS}\left(30 \mathrm{~min}\right.$ at $\left.50^{\circ} \mathrm{C}\right)$ and washed with $2 \times \mathrm{SSC}(3 \mathrm{~min})$ and $0.2 \times \operatorname{SSC}(3 \mathrm{~min})$ and hybridized overnight in cocktail containing $1.3 \times$ Denhardt's, $3 \times$ SSC $0.3 \%$ SDS, $2.1 \mu \mathrm{g} / \mu$ l polyadenylate and $1 \mu \mathrm{g} / \mu \mathrm{l}$ yeast tRNA. Signal was captured, processed and segmented using an Agilent scanner (G2565B, AgilentTechnologies) by the Agilent Feature ExtractionSoftware (v9.5) with the protocol GE1-v5_95, extended dynamic range and preprocessing by the Agilent feature extraction. Normalization within each microarray was carried out by using the mean of tetraplicates of the rplp0 gene http://www.ncbi.nlm.nih.gov/geo/query/acc. cgi?acc=GSE19049. The gProccesedSignal was chosen for statistical analysis. Data was first filtered by nonuniform pixel distributed outliers and other replicate outliers (glsFeatNonUnifOL, glsBGNonUnifOL, 
glsFeatPopnOL and glsBGPopnOL) according to the default Agilent feature extraction criteria; ratio between processed signal and its error $<2$; differentiation from background signal; linear relationship between concentration and intensity below limits according to Spike-In information and/or, at least 2 quality biological replicates out of 4 . The list of sequences was searched for each of the immune-related gene keywords defined above and analysis continued with those selected 636 genes (the rest of the genes will be analyzed and reported elsewhere). For each immune-related gene the Student $\mathrm{t}$ one tail statistic associated $\mathrm{p}$ was computed and fold calculated by the formula, mean of VHSVinfected values/mean of non-infected values. A double simultaneous criterion was used to identify differentially expressed genes: i) genes with ratios VHSV-infected/ non-infected $>2$ and ii) genes which deviated from the null hypothesis using the $\mathrm{t}$-test at $\mathrm{p}<0.05$. Calculations were made from 4 biological replicates VHSV-infected and non-infected each and by 2 independent researchers using Microsoft Excel, Origin pro SR4, BRB-Array Tools and the TIGR Multiple array viewer program $(\mathrm{MeV})$ (see above) and their results confronted until all discrepancies were solved.

\section{List of abbreviations}

EST: express sequence tag; F-ACTIN: filamentous actin; FFU: focus forming units; HMGB1: high mobility group protein 1; HRV: hirame rhabdovirus; IHNV: infectious haematopoietic necrosis virus; KDA: kilo Daltons; MS: mass espectrophotometry; MW: molecular weight; PAGE: polyacrylamide gel electrophoresis; PCR: polymerase chain reaction; PI: isoelectric point; RPLPO: ribosomal phosphoprotein p0; RT-Q-PCR: reverse transcriptase quantitative polymerase chain reaction; SDS: sodium dodecyl sulfate; SVCV: spring viremia carp virus; 2D-DIGE: two dimensional differential gel electrophoresis: VHSV: Viral haemorrhagic septicemia virus.

\section{Authors' contributions}

PE and BN performed the RT-Q-PCR and experimental viral infections. MAR and AF carried out the statistical Q-PCR and microarray data analysis. AE and $J C$ design experiments, coordinate the work and drafted-write the manuscript. All authors read and approved the manuscript.

\section{Acknowledgements}

Thanks are due to Dr. Paulino Martinez Portela and his group of Universidad de Lugo, Spain, for the carrying out of microarray hybridizations and to $S$. Carbajosa for help in the initial stages of experimentation. This work was supported by CICYT projects AGL08-03519-CO4-ACU and INGENIO 2010 CONSOLIDER 2007-00002 of the Ministerio de Ciencia e Innovación of Spain.

\section{Author details}

'Instituto Nacional Investigaciones Agrarias, Dpto. Biotecnología. INIA. Crt. La Coruña, Km. 7, 28040 - Madrid, Spain. ${ }^{2}$ Instituto Investigaciones Marinas, CSIC, Eduardo Cabello 6, 36208 Vigo, Spain. ${ }^{3}$ Universidad Miguel Hernández, IBMC, 03202 Elche, Spain.

Received: 5 April 2010 Accepted: 27 September 2010 Published: 27 September 2010

\section{References}

1. Kurath G, Purcell MK, Garver KA: Fish rhabdovirus models for understanding host response to DNA vaccines. CAB reviews 2007, 2:1-12.
2. Sullivan $\mathrm{C}, \mathrm{Kim} \mathrm{CH}$ : Zebrafish as a model for infectious disease and immune function. Fish \& Shellfish Immunol 2008, 25:341-350.

3. Slierendrecht WJ, Olesen NJ, Juul-Madsen HR, Lorenzen N, Henryon M, Berg P, Sondergaard J, Koch C: Rainbow trout offspring with different resistance to viral haemorrhagic septicaemia. Fish \& Shellfish Immunol 2001, 11(2):155-167.

4. Yamamoto S, Sanjyo I, Sato R, Kohara M, Tahara H: Estimation of the Heritability for Resistance to Infectious Hematopoietic Necrosis in Rainbow-Trout. Nippon Suisan Gakkaishi 1991, 57(8):1519-1522.

5. Quillet E, Dorson M, Le Guillou S, Benmansour A, Boudinot P: Wide range of susceptibility to rhabdoviruses in homozygous clones of rainbow trout. Fish \& Shellfish Immunol 2007, 22(5):510-519.

6. Harmache A, LeBerre M, Droineau S, Giovannini M, Bremont M: Bioluminescence imaging of live infected salmonids reveals that the fin bases are the major portal of entry for Novirhabdovirus. J Virol 2006, 80(7):3655-3659.

7. Costes B, Raj VS, Michel B, Fournier G, Thirion M, Gillet L, Mast J, Lieffrig F, Bremont M, Vanderplasschen A: The major portal of entry of koi herpesvirus in Cyprinus carpio is the skin. J Virol 2009, 83(7):2819-2830.

8. Novoa B, Romero A, Mulero V, Rodriguez I, Fernandez I, Figueras A: Zebrafish (Danio rerio) as a model for the study of vaccination against viral haemorrhagic septicemia virus (VHSV). Vaccine 2006, 24(3132):5806-5816.

9. Kurath G: Biotechnology and DNA vaccines for aquatic animals. Rev Sci Tech 2008, 27(1):175-196

10. LaPatra SE, Barone L, Jones GR, Zon LI: Effects on infectious hematopoietic necrosis virus and infectious necrosis virus infection on hematopoietic precursosrs of the zebrafish. Blood Cell Molecular Diseases 2000, 26:445-452.

11. Phelan PE, Pressley ME, Witten PE, Mellon MT, Blake S, Kim CH: Characterization of snakehead rhabdovirus infection in zebrafish (Danio rerio). J Virol 2005, 79:1842-1852.

12. Sanders GE, Batts WN, Winton JR: Susceptibility of zebrafish (Danio rerio) to a model pathogen, spring viremia of carp virus. Comp Med 2003, 53:514-521.

13. LeMorvan C, Troutaud D, Deschaux P: Differential effects of temperature on specific and nonspecific immune defences in fish. J Exp Biol 1998, 201:165-168.

14. Ahne W, Bjorklund HV, Essbauer S, Fijan N, Kurath G, Winton JR: Spring viremia of carp (SVC). DisAquatic Org 2002, 52:261-272.

15. Fernandez-Alonso M, Rocha A, Coll JM: DNA vaccination by immersion and ultrasound to trout viral haemorrhagic septicaemia virus. Vaccine 2001, 19:3067-3075.

16. Levraud JP, Boudinot P, Colin I, Benmansour A, Peyrieras N, Herbomel P, Lutfalla G: Identification of the Zebrafish IFN Receptor: Implications for the Origin of the Vertebrate IFN System. J Immunol 2007, 178(7):4385-4394.

17. Nam BH, Yamamoto E, Hirono I, Aoki T: A survey of expressed genes in the leukocytes of Japanese flounder, Paralichthys olivaceus, infected with Hirame rhabdovirus. Dev Comp Immunol 2000, 24:13-24.

18. Aoki T, Nam BH, Hirono II, Yamamoto E: Sequences of 596 cDNA Clones (565,977 bp) of Japanese Flounder (Paralichthys olivaceus) Leukocytes Infected with Hirame Rhabdovirus. Mar Biotechnol (NY) 1999, 1:477-0488.

19. Kurobe T, Yasuike M, Kimura T, Hirono I, Aoki T: Expression profiling of immune-related genes from Japanese flounder Paralichthys olivaceus kidney cells using CDNA microarrays. Dev Comp Immunol 2005, 29(6):515-523

20. MacKenzie S, Balasch JC, Novoa B, Ribas L, Roher N, Krasnov A, Figueras A: Comparative analysis of the acute response of the trout, O. mykiss, head kidney to in vivo challenge with virulent and attenuated infectious hematopoietic necrosis virus and LPS-induced inflammation. BMC Genomics 2008, 9:141.

21. Yasuike M, Kondo H, Hirono I, Aoki T: Difference in Japanese flounder, Paralichthys olivaceus gene expression profile following hirame rhabdovirus (HIRRV) $\mathrm{G}$ and N protein DNA vaccination. Fish \& Shellfish Immunol 2007, 23:531-541.

22. Byon JY, Ohira T, Hirono I, Aoki T: Comparative immune responses in Japanese flounder, Paralichthys olivaceus after vaccination with viral hemorrhagic septicemia virus (VHSV) recombinant glycoprotein and DNA vaccine using a microarray analysis. Vaccine 2006, 24:921-930. 
23. Purcell MK, Nichols KM, Winton JR, Kurath $G$, Thorgaard GH, Wheeler $P$, Hansen JD, Herwig RP, Park LK: Comprehensive gene expression profiling following DNA vaccination of rainbow trout against infectious hematopoietic necrosis virus. Mol Immunol 2006, 43:2089-2106.

24. Whitehead GG, Makino S, Lien CL, Keating MT: fgf 20 is essential for initiating zebrafish fin regeneration. Science 2005, 310(5756):1957-1960.

25. Bianchi ME, Manfredi AA: High-mobility group box 1 (HMGB1) protein at the crossroads between innate and adaptive immunity. Immunol Rev 2007, 220:35-46

26. Lambrecht BN, Kool M, Willart MA, Hammad $\mathrm{H}$ : Mechanism of action of clinically approved adjuvants. Curr Opin Immunol 2009, 21(1):23-29.

27. Kamau E, Takhampunya R, Li T, Kelly E, Peachman KK, Lynch JA, Sun P, Palmer DR: Dengue virus infection promotes translocation of high mobility group box 1 protein from the nucleus to the cytosol in dendritic cells, upregulates cytokine production and modulates virus replication. J Gen Virol 2009, 90(Pt 8):1827-1835.

28. Muthumani G, Laddy DJ, Sundaram SG, Fagone P, Shedlock DJ, Kannan S, Wu L, Chung CW, Lankaraman KM, Burns John, et al: Co-immunization with an optimized plasmid-encoded immune stimulatory interleukin, high-mobility group box 1 protein, results in enhanced interferon-c secretion by antigen-specific CD8 T cells. Immunology 2009, 128:612-620.

29. Kimura R, Shiibashi R, Suzuki M, Hayashizaki Y, Chiba J: Enhancement of antibody response by high mobility group box protein-1-based DNA immunization. J Immunol Methods 2010, 1872-7905, online (electronic).

30. Joosen R, Cordewener J, Supena ED, Vorst O, Lammers M, Maliepaard C, Zeilmaker T, Miki B, America T, Custers J, et al: Combined transcriptome and proteome analysis identifies pathways and markers associated with the establishment of rapeseed microspore-derived embryo development. Plant Physiol 2007, 144(1):155-172.

31. Gallardo K, Firnhaber C, Zuber H, Hericher D, Belghazi M, Henry C, Kuster H, Thompson R: A combined proteome and transcriptome analysis of developing Medicago truncatula seeds: evidence for metabolic specialization of maternal and filial tissues. Mol Cell Proteomics 2007, 6(12):2165-2179

32. Taniguchi Y, Choi PJ, Li GW, Chen H, Babu M, Hearn J, Emili A, Xie XS: Quantifying E. coli proteome and transcriptome with single-molecule sensitivity in single cells. Science 2010, 329(5991):533-538.

33. Giannakopoulos NV, Luo JK, Papov V, Zou W, Lenschow DJ, Jacobs BS, Borden EC, Li J, Virgin HW, Zhang DE: Proteomic identification of proteins conjugated to ISG15 in mouse and human cells. Biochem Biophys Res Commun 2005, 336(2):496-506.

34. Hack CJ: Integrated transcriptome and proteome data: the challenges ahead. Brief Funct Genomic Proteomic 2004, 3(3):212-219.

35. Acosta F, Collet B, Lorenzen N, Ellis AE: Expression of the glycoprotein of viral haemorrhagic septicaemia virus (VHSV) on the surface of the fish cell line RTG-P1 induces type 1 interferon expression in neighbouring cells. Fish \& Shellfish Immunol 2006, 21:272-278.

36. Samuel CE: Antiviral Actions of Interferons. Clin Microbiol Rev 2001, 14(4):778-809.

37. Tafalla C, Coll J, Secombes CJ: Expression of genes related to the early immune response in rainbow trout (Oncorhynchus mykiss) after viral haemorrhagic septicemia virus (VHSV) infection. Dev Comp Immunol 2005, 29(7):615-626.

38. Tafalla C, Chico V, Perez L, Coll JM, Estepa A: In vitro and in vivo differential expression of rainbow trout (Oncorhynchus mykiss) $\mathrm{Mx}$ isoforms in response to viral haemorrhagic septicaemia virus (VHSV) G gene, poly I:C and VHSV. Fish Shellfish Immunol 2007, 23:210-221.

39. Byon JY, Ohira T, Hirono I, Aoki T: Use of a cDNA microarray to study immunity against viral hemorrhagic septicemia (VHS) in Japanese flounder (Paralichthys olivaceus) following DNA vaccination. Fish \& Shellfish Immunology 2005, 18(2):135-147.

40. von Schalburg KR, Rise ML, Cooper GA, Brown GD, Gibbs AR, Nelson CC, Davidson WS, Koop BF: Fish and chips: various methodologies demonstrate utility of a 16,006-gene salmonid microarray. BMC Genomics 2005, 6:126.

41. Magnadottir B: Innate immunity of fish (overview). Fish \& Shellfish Immunology 2006, 20:137-151.

42. Nikoskelainen S, Bylund G, Lilius EM: Effect of environmental temperature on rainbow trout (Oncorhynchus mykiss) innate immunity. Dev Comp Immunol 2004, 28:581-592.
43. Sunyer JO, Boshra H, Lorenzo G, Parra D, Freedman B, Bosch N: Evolution of complement as an effector system in innate and adaptive immunity. Immunol Res 2003, 27(2-3):549-564.

44. Slierendrecht WJ, Olesen NJ, Lorenzen N, Jorgensen PEV, Gottschau A Koch C: Genetic alloforms of rainbow trout (Oncorhynchus mykiss) complement component $\mathrm{C} 3$ and resistance to viral haemorrhagic septicaemia under experimental conditions. Fish \& Shellfish Immunol 1996, 6:235-237.

45. Sunyer JO, Boshra H, Li J: Evolution of anaphylatoxins, their diversity and novel roles in innate immunity: insights from the study of fish complement. Vet Immunol Immunopathol 2005, 108(1-2):77-89.

46. Hansen JD, La Patra S: Induction of the rainbow trout MHC class I pathway during acute IHNV infection. Immunogenetics 2002, 54(9):654-661.

47. diLorio PJ, Runko A, Farrell CA, Roy N: Sid4: A secreted vertebrate immunoglobulin protein with roles in zebrafish embryogenesis. Dev Biol 2005, 282(1):55-69.

48. Bassett DI: Identification and developmental expression of a macrophage stimulating $1 /$ hepatocyte growth factor-like 1 orthologue in the zebrafish. Dev Genes Evol 2003, 213(7):360-362.

49. Won WJ, Bachmann MF, Kearney JF: CD36 is differentially expressed on B cell subsets during development and in responses to antigen. J Immunol 2008, 180(1):230-237.

50. Wright AK, Briles DE, Metzger DW, Gordon SB: Prospects for use of interleukin-12 as a mucosal adjuvant for vaccination of humans to protect against respiratory pneumococcal infection. Vaccine 2008, 26(38):4893-4903.

51. Miossec $P$, Korn T, Kuchroo VK: Interleukin-17 and type 17 helper T cells. N Engl J Med 2009, 361(9):888-898.

52. Falco A, Coll JM, Estepa A: Antimicrobial peptides as model molecules for the development of novel antiviral agents in Aquaculture. Mini-reviews in Medicinal Chemistry 2009, 9:1159-1164

53. Yu JJ, Gaffen SL: Interleukin-17: a novel inflammatory cytokine that bridges innate and adaptive immunity. Front Biosci 2008, 13:170-177.

54. Pardo BG, Fernandez C, Millan A, Bouza C, Vazquez-Lopez A, Vera M, Alvarez-Dios JA, Calaza M, Gomez-Tato A, Vazquez M, et al: Expressed sequence tags (ESTs) from immune tissues of turbot (Scophthalmus maximus) challenged with pathogens. BMC Vet Res 2008, 4:37-49.

55. Park KC, Osborne JA, Montes A, Dios S, Nerland AH, Novoa B, Figueras A, Brown LL, Johnson SC: Immunological responses of turbot (Psetta maxima) to nodavirus infection or polyriboinosinic polyribocytidylic acid (pIC) stimulation, using expressed sequence tags (ESTs) analysis and cDNA microarrays. Fish \& Shellfish Immunology 2009, 26:91-108.

56. Martin SA, Zou J, Houlihan DF, Secombes CJ: Directional responses following recombinant cytokine stimulation of rainbow trout (Oncorhynchus mykiss) RTS-11 macrophage cells as revealed by transcriptome profiling. BMC Genomics 2007, 8:150.

57. Falco A, Brocal I, Perez L, Coll JM, Estepa A, Tafalla C: In vivo modulation of the rainbow trout (Oncorhynchus mykiss) immune response by the human alpha defensin 1, HNP1. Fish \& Shellfish Immunol 2008, 24(1):102-112.

58. Lorenzo G, Estepa A, Coll JM: Fast neutralization/immunoperoxidase assay for viral haemorrhagic septicemia with anti-nucleoprotein monoclonal antibody. J Virol Methods 1996, 58:1-6.

59. Ruiz S, Schyth BD, Encinas P, Tafalla C, Estepa A, Lorenzen N, Coll JM: New tools to study RNA interference to fish viruses: Fish cell lines permanently expressing siRNAs targeting the viral polymerase of viral hemorrhagic septicemia virus. Antiviral Res 2009, 82(3):148-156.

doi:10.1186/1471-2164-11-518

Cite this article as: Encinas et al:: Zebrafish fin immune responses during high mortality infections with viral haemorrhagic septicemia rhabdovirus. A proteomic and transcriptomic approach. BMC Genomics $201011: 518$. 